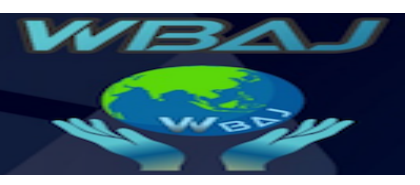

Volume 1 Issue 2, Desember 2019

http:/ / ejournal.unsub.ac.id/index.php/bisnis

\title{
Pengaruh Motivasi Terhadap Produktifitas Kerja Karyawan PT.Fastrata Buana
}

Komir Bastaman

Fakultas Ilmu Administrasi Universitas Subang

komirbastaman60@gmail.com

\begin{abstract}
Abstrak
Hasil penelitian menjelaskan bahwa variabel motivasi ternyata didominasi oleh pendapat yang menyatakan setuju terhadap variabel motivasi menjadi angka mayorias sebesar $43 \%$, jawaban yang menyatakan sangat setuju sebesar 34\%, jawaban ragu-ragu sebesar $17 \%$, jawaban tidak setuju $5 \%$ dan yang menjawab sangat tidak setuju memiliki angka minoritas yaitu sebesar $1 \%$. Variabel produktivitas kerja ternyata didominasi oleh pendapat yang menyatakan setuju terhadap variabel produktivitas kerja menjadi angka mayoritas yaitu 46\%, jawaban yang menyatakan sangat setuju sebesar 32\%, jawaban ragu-ragu sebesar 18\%, jawaban tidak setuju 3\% dan yang menjawab sangat tidak setuju memiliki angka minoritas yaitu sebesar 1\%. Sedangkan besaran pengaruh motivasi terhadap produktivitas kerja yaitu sebesar variabel independen (motivasi kerja) mempengaruhi variabel dependen (produktivitas kerja) sebesar 50,3\% dan sisanya sebesar 49,7\% yang diperkirakan dipengaruhi oleh faktor lain tidak diteliti lebih lanjut oleh peneliti melainkan dapat ditelitu oleh peneliti lain sebagai acuan untuk diteliti dan dikembangkan lagi.Kesimpulan dalam penelitian ini yakni bahwa perediks pengaruh motivas terhadap produktivitas kerja bersifat positif. Artinya, motivasi berpengaruh besar terhadap penigkatan produktivitas kerja.
\end{abstract}

Kata Kunci : Motivasi, Kinerja karyawan

\section{Abstract}

The results of the study explained that the motivation variable turned out to be dominated by the opinion that states agree to motivational variables into numbers mayorias by $43 \%$, the answers to which states could not agree by $34 \%$, the answer hesitation by $17 \%$, the answers do not agree $5 \%$ and were answered very agreed to have a figure that is equal to $1 \%$ minority. Variable labor productivity turned out to be dominated by the opinion that states agree to variable labor 


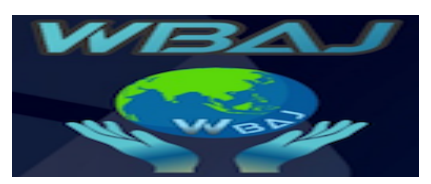

Volume 1 Issue 2, Desember 2019

http:/ / ejournal.unsub.ac.id/index.php/bisnis

productivity into numbers the majority, ie $46 \%$, an answer that states could not agree by $32 \%$, the answer hesitant at $18 \%$, the answers do not agree to $3 \%$, and the answer strongly disagree have minority numbers: $1 \%$. While the magnitude of the effect of motivation to work productivity that is equal to the independent variable (motivation to work) affect the dependent variable (labor productivity) of $50.3 \%$ and the balance of $49.7 \%$ is expected to be influenced by other factors not examined further by investigators but can ditelitu by other researchers as a benchmark for researched and developed again. The conclusion of this study namely that perediks motivas influence on the productivity of labor is positive. That is, the motivation big influence on the progressive increase in labor productivity.

Keywords: Motivation, employee performance

\section{Pendahuluan}

Pada saat ini perkembangan usaha bisnis sangat pesat sehingga dengan sendirinya muncul tingkat persaingan yang semakin tajam diantara para pengusaha (Perusahaan). Hal ini menyebabkan para pengusaha meningkatkan sumber daya manusia. Satu hal yang penting yaitu bahwa keberhasilan berbagai aktivitas didalam perusahaan dalam mencapai tujuan bukan hanya tergantung pada sarana atau pun prasarana yang dimiliki dan dana operasi yang tersedia melainkan juga tergantung pada aspek sumber daya manusia. Satu hal yang penting yaitu bahwa keberhasilan berbagai aktivitas di dalam perusahaan dalam mencapai tujuan bukan hanya tergantung pada sarana atau pun perasarana yang dimiliki dan dana operasi yang tersedia bukan hanya tergantung pada aspek sumber daya manusia. Faktor sumber daya manusia ini merupakan elemen yang harus diperhatikan oleh perusahaan, terutama bila mengingat bahwa era perdagangan bebas akan segera dimulai, dimana iklim kompetisi yang dihadapi akan sangat berbeda. Kualitas dan kuantitas Sumber Daya Manusia dalam suatu organisasi hendaknya disesuaikan dengan kebutuhan organisasi atau perusahaan yang bersangkutan agar efektif dan efesisensi dalam menunjang tercapainya tujuan organisasi atau perusahaan

Sumber daya manusia adalah faktor utama perusahaan yang berperan penting bagi perusahaan untuk menjalankan kegiatannya dengan baik. Oleh karena itu, perusahaan harus mempunyai sumber daya manusia yang memiliki tingkat pengetahuan dan kemampuan yang tinggi serta usaha untuk mengelola perusahaan seoptimal mungkin sehingga produktifitas akan karyawan meningkat. Perusahaan dan karyawan merupakan dua hal yang saling membutuhkan Jika karyawan berhasil membawa kemajuan bagi perusahaan, keuntungan yang diperoleh akan dapatkan oleh kedua belah pihak. Bagi karyawan keberhasilan merupakan aktualisasi potensi diri sekaligus peluang untuk memenuhi kebutuhan hidupnya sedangkan bagi perusahaan, keberhasilan merupakan sarana menuju pertumbuhan dan perkembangan perusahaan. Menyadari bahwa Sumber Daya Manusia sebagai salah satu faktor utama dalam 
rangka menentukan kinerja perusahaan. Maka perusahaan kini menaruh perhatian terhadap pengembangan Sumber Daya Manusia. Seberapun majunya teknologi dan perkembangan informasi, dan tersediannya modal dan bahan yang memadai jika tanpa SDM sulit bagi organisasi untuk mencapai tujuannya. Oleh karena itu keberadaan sumber daya manusia di dalam suatu perusahaan memegang peranan yang sangat besar bagi kesuksesan suatu perusahaan, Banyak perusahaan menyadari bahwa unsur dalam suatu perusahaan dapat memberikan keunggulan bersaing, perusahaan membuat sasaran, inovasi, dalam mencapai tujuan perusahaan. Oleh karena itu, SDM merupakan salah satu unsur yang sangat penting dalam suatu perusahaan. Pelaksanaan pekerjaan oleh karyawan dilingkungan perusahaan pada dasarnya berlangsung dalam kondisi karyawan sebagai manusia, suasana batin/psikologis seorang karyawan sangat besar pengaruhnya pada pelaksanaan pekerjaannya. Hal ini terlihat dalam semangat atau gairah kerja yang menghasilkan kegiatan kerja sebagai kontribusi bagi pencapaiantujuan bisnis perusahaan tempatnya bekerja.

Hal ini memaksa setiap perusahaan harus dapat bekerja dengan lebih efesisen, efektif dan produktif. Tingkat kompetisi yang tinggi akan memacu tiap perusahaan untuk dapat mempertahankan kelangsungan hidupnya dengan memberikan perhatian pada aspek sumber daya manusia. Jadi manusia dapat dipandang sebagai faktor penentu karena ditangan manusialah segala tugas, pekerjaan serta inovasi akan terwujud dalam upaya mencapai tujuan perusahaan. Karyawan pada hakekatnya merupakan salah satu unsur yang menjadi sumber daya dalam perusahaan. Sumber daya manusia inilah yang menjalankan kegiatan sehari - hari, karyawan merupakan Living organisme memungkinkan berfungsinya suatu organisasi atau perusahaan dan menjadi unsur penting dalam manajemen. Agar pekerjaan dapat melaksanakan tugasnya dengan baik, maka di dalam perusahaan diciptakan system manajemen yang dikenal dengan manajemen kepegawaian.

Karyawan yang memiliki semangat kerja yang tinggi akan meningkatkan kehidupan organisasi atau perusahaan. Loyalitas dan semangat kerja dapat dilihat dari mereka merasa senang dengan pekerjaannya. Mereka akan memberikan lebih banyak perhatian, imajinasi dan keterampilan dalam pekerjaannya. Dengan demikian diperlukan suatu motivator bagi karyawan yaitu berupa pemenuhan kebutuhan fisik dan non fisik. Dengan terpenuhinya kebutuhan tersebut maka karyawan akan bersedia bekerja dan melaksanakan tugasnya dengan baik. Mereka akan lebih memusatkan perhatiannya terhadap tugas dan tanggung jawabnya, sehingga hasil pekerjaan yang dicapai dapat meningkat. Untuk itulah dibutuhkan suatu dorongan bagi karyawan di dalam menyelenggarakan kegiatan di suatu perusahaan. Dorongan itulah yang disebut motivasi. Motivasi sebagaimana diungkapkan Wursanto (2001: 132) dalam Hasibuan adalah alasan, dorongan yang ada di dalam diri manusia yang menyebabkan manusia melakukan sesuatu atau berbuat sesuatu. Motivasi karyawan dapat dipengaruhi faktor minat, gaji yang diterima, kebutuhan akan rasa aman, hubungan antar personal dan kesempatan untuk bekerja.

Setiap perusahaan berupaya untuk mendapatkan karyawan yang terlibat dalam kegiatan organisasi / perusahaan dapat memberikan prestasi kerja. Dalam 
bentuk produktivitas kerja setinggi mungkin untuk mewujudkan tujuan yang telah ditetapkan sebelumnya. Terdapat banyak faktor yang dapat mempengaruhi produktivitas diantaranya semangat kerja dan disiplin kerja, tingkat pendidikan, ketrampilan, gizi dan kesehatan, sikap dan etika, motivasi, iklim kerja, teknologi, sarana produksi, kesempatan kerja dan kesempatan berprestasi Untuk mencapai produktivitas yang tinggi pimpinan perusahaan harus memperhatikan semangat kerja dan disiplin kerja. Semangat kerja merupakan sikap mental yang mampu memberikan dorongan bagi seseorang untuk dapat bekerja lebih giat, cepat, dan baik. Semangat kerja karyawan yang tinggi akan berpengaruh terhadap efisiensi kerja dan efektivitas kerja. Hilangnya disiplin akan berpengaruh terhadap efisiensi kerja dan efektivitas tugas pekerjaan. Dengan adanya kedisiplinan diharapkan pekerjaan akan dilakukan seefektif mungkin. Bilamana kedisiplinan tidak dapat ditegakkan maka kemungkinan tujuan yang telah ditetapkan tidak dapat dicapai secara efektif dan efisien. Seperti kita ketahui, pada umumnya perusahaan harus bisa mempertahankan citranya agar dapat memperluas/menguasai pangsa pasar. Dalam hal ini perusahaan juga harus bisa meningkatkan kualitas perusahaan misalnya dari segi intern perusahaan itu sendiri antara lain peningkatan kualitas karyawan. Kualitas karyawan dapat dilihat dari motivasi yang di berikan perusahan kepada karyawan melalui semangat dan disiplin karyawan diharapkan dapat meningkatkan input perusahaan yang dapat mendatangkan profit. Dalam melakukan kegiatan produksinya hampir semua menggunakan tenaga kerja manusia, sehingga dalam proses produksi memerlukan ketrampilan tenaga kerja manusia yang handal yang nantinya akan dapat meningkatkan produktifitas yang telah ditentukan oleh perusahaan. Diperlukan motivasi yang tinggi untuk mendorong karyawan untuk melakukan usaha sehingga yang dilakukan diharapkan dapat mencapai tujuan perusahaan. Salah satu tujuan perusahaan adalah mendapatkan laba yang bisa di dapat dengan produktifitas yang tinggi. Motivasi adalah suatu dorongan untuk memicu seorang individu dalam melakukan sesuatu kegiatan ataupun pekerjaan dalam sebuah perusahaan supaya dapat bekerja lebih maksimal atau sesuai dengan apa yang di harapkan, maka dari itu ada juga yang mengartikan motivasi sama dengan semangat. Salah satu yang memicu motivasi di setiap individu yaitu kebutuhan, karena setiap individu memiliki sifat dan kepribadian yang berbeda maka kebutuhannya pun akan berbeda, jika kebutuhanya sudah tepenuhi maka motivasi bekerjanya menjadi tinggi dan akan bekerja lebih baik dari sebelumnya sehingga akan tercapainya tujuan perusahaan, oleh karena itu motivasi menjadi peranan penting dalam sebuah produktivitas kerja jika motivasi karyawan di perusahaan itu tinggi maka perusahaan tersebut akan menjadi perusahaan yang maju dan berkembang. Produtivitas kerja merupakan suatu ukuran pengoptimalan terhadap hasil yang di capai oleh sebuah perusahaan, produktivitas juga bisa dikatakan sebagai tolak ukur keberhasilan suatu perusahaan. Produktivitas merupakan hal yang diperhatikan oleh perusahaan maka perusahaan harus memikirkan antisipasi jika ada permasalahan yang mempengaruhi terhadap produktivitasnya dan juga harus memikirkan antisipasi untuk kemungkinan terburuk dalam produktivitasnya. Salah satu masalah yang sering dihadapi organisasi atau 
perusahaan dalam meningkatkan produktivitasnya adalah karyawan atau anggotanya yang kurang maksimal melakukan pekerjaannya. Seorang pimpinan harus menentukan cara yang paling terbaik yang harus ditempuh agar dapatmenggerakan dan meningkatkan produktivitas kerja karyawanya secarasadar dan bertanggungjawab melaksanakan tugasnya sehingga karyawan dapat terdorong untuk bekerja dengan sebaik-baiknya. dalam menentukan cara untuk mengantisipasi hal tersebut pimpinan harus memiliki pertimbangan agar dalam upaya peningkatan produktivitas kerja setiap karyawanya bisa berjalan dengan baik dan dapat menggerakan kemampuan terbaiknya dalam bekerja, salah satu yang menjadi pertimbangan yaitu kebutuhan para setiap karyawanya baik kebutuhan secara fisik maupun kebutuhan rasa aman dan nyaman dalam melakukan bekerja karena jika kebutuhan para karyawan sudah terpenuhi maka motivasi untuk bekerja juga akan terbentuk dan akan sesuai dengan apa yang di tetapkan oleh perusahaan atau tujuan perusahaan. Begitu juga pada objek penelitian yang saya usulkan yaitu di PT.Fastrata Buana di Subang, karyawan yang ada dalam PT.Fastrata Buana sebanyak 75 orang. Apabila kebutuhan serta keinginan karyawan sudah terpenuhi, maka mereka akan melaksanakan dan pekerjaanya dengan baik serta juga akan lebih bersemangat dalam bekerja sehingga karyawan itu memiliki kesanggupan atas tugas yang dibebankan, kesanggupan untuk bekerja sama serta sanggup menaati peraturan berorganisasi. Sebagai suatu perusahaan yang juga menginginkan agar produktifitas karyawannya selalu meningkat, mampu mencapai target yang ditetapkan perusahaan, pelanggan yang diperoleh dapat dipertahankan, dan dapat memperoleh pelanggan baru, PT.Fastrata Buana di Subang sebagai perusahaan yang cukup besar dan mempunyai beberapa cabang yang tersebar diseluruh Indonesia, juga tidak luput dari hal tersebut. Berikut ini dapat dilihat data target penjualan dan realisasi pencapaian target penjualan yang disajikan pada tabel 1.1 di bawah ini:

Tabel 1

Data Penjualan PT.Frasrata Buana di Subang

\begin{tabular}{|l|l|l|l|}
\hline Tahun & Target Penjualan (Rp) & $\begin{array}{c}\text { Realilasi Penjualan } \\
(\mathrm{Rp})\end{array}$ & $\begin{array}{c}\text { Pencapaian } \\
\text { Target Penjualan } \\
(\mathrm{Rp})\end{array}$ \\
\hline 2011 & $15.887 .906 .000,00$ & $18.966 .886 .000,00$ & $119,37 \%$ \\
\hline 2012 & $16.887 .985 .807,00$ & $12.508 .617 .242,00$ & $74,06 \%$ \\
\hline 2013 & $17.638 .958 .928,00$ & $15.324 .715 .320,00$ & $87,88 \%$ \\
\hline 2014 & $18.232 .986 .876,00$ & $18.986 .875 .880,00$ & $104,13 \%$ \\
\hline 2015 & $15.658 .856 .844,00$ & $11.643 .475 .234,00$ & $74,35 \%$ \\
\hline
\end{tabular}

Sumber : Data Perusahaan PT.Frasrata Buana

Dari tampilan dari tabel 1 diatas, ternyata realisasi penjualan di PT.Fastrata Buana dari Tahun 2011 - 2015 mengalami fluktuasi serta realisasi penjualan masih di bawah target penjualan yang ditetapkan perusahaan, hanya pada Tahun 2011 dan 2014 saja yang melebihi target penjualan. Pada 2014 terjadi peningkatan penjualan yang sangat tajam melebihi target penjualan Tahunan 2011, namun Tahun 2012, 2013 sampai dengan Tahun 2015 mengalami penurunan penjualan. Pada observasi awal penelitian 
ini terdapat beberapa permasalahan pada PT.Fastrata Buana di Subang, yaitu masihendahnya kinerja karyawan hal ini terlihat dari indikator sebagai berikut : 1) Masih adanya beberapa karyawan bermalas- malasan pada waktu kerja yang bekerja hanya kalau ada tugas dari pimpinan, mereka tidak secara mandiri atau kreatif menyelesaikan pekerjaan nya dengan baik dan cepat, fenomena tersebut menunjukkan bahwa sikap karyawan masih harus diarahkan untuk dapat memperbaiki produktifitas kerja; Contohnya : ada beberapa karyawan yang mengisi waktu kerjanya dengan duduk-duduk santai-santai dalam melakukan pekerjaannya, dan masih banyak para karyawan tidak selesai tepat waktu dalam pengiriman barang- barang ke toko-toko yang sudah memesan barang tersebut, yang seharusnya pekerjaan tersebut dapat diselesaikan dengan waktu 1 jam, dengan waktu tersebut pekerjaannya tidak dapat diselesaikan sehingga target pengiriman tidak tercapai dengan waktu yang telah ditentukan. Ditemui juga kurangnya kontrol dan sanksi yang tegas dari pimpinan. Contohnya: Ketika ada karyawan yang melakukan kesalahan dalam pekerjaannya, atau bahkan pada saat jam kerja karyawan hanya duduk-duduk santai, tidak ada pngawasan dan sanksi tegas yang diberikan. Sehingga hal inilah yang membuat kinerja karyawan rendah.

\section{Keraangka Teori}

\section{a. Konsep Manajemen Sumber Daya Manusia}

MSDM adalah suatu manajemen yang khusus mempelajari hubungan dan peranan manusia dalam organisasi perusahaan. Unsur MSDM adalah manusia yang merupakan tenaga kerja pada perusahaan, fokus yang dipelajari MSDM ini hanya masalah yang berhubungan dengan tenaga kerja manusia saja. Manusia selalu berperan aktif dan dominan dalam setiap kegiatan organisasi, karena manusia menjadi perencanaan, perilaku, dan penentu terwujudnya tujuan organisasi. Tujuan tidak mungkin terwujud tanpa peran aktif karyawan meskipun alat-alat yang dimiliki perusahaan begitu canggihnya. Alat-alat canggih yang dimiliki perusahaan tidak ada manfaatnya bagi perusahaan. Jika peran aktif karyawan tidak diikutsertakan. Mengatur karyawan adalah sulit dan kompleks, karena mereka mempunyai pikiran, perasaan status, keinginan, dan latar belakang yang heterogen yang dibawa ke dalam organisasi. Karyawan tidak dapat diatur dan dikuasai sepenuhnya seperti mengatur mesin, modal, atau gedung. Menurut Hasibuan (2001 : 10) mengemukakan bahwa manajemen sumber daya manusia adalah ilmu dan seni mengatur hubungan dan peranan tenaga kerja agar efektif dan efisien membantu terwujudnya tujuan perusahaan, karyawan, dan masyarakat. Menurut Gomes (2002 : 4) dalam Handoko mengemukakan bahwa manajemen sumber daya manusia adalah pengembangan dan pemanfaatan personil (pegawai) bagi pencapaian yang efektif mengenai sasaran-sasaran dan tujuan-tujuan individual, organisasi, masyarakat, nasional, dan internasional. Menurut Simamora (2003 : 4) dalam Sondang siagian bahwa manajemen sumber daya manusia adalah pendayagunaan pengembangan, penilaian, pemberian balas jasa, dan pengelolaan 
individu anggota organisasi atau kelompok karyawan. Hal yang sama dikemukakan oleh Heidjrachman dan Husman (2002 : 5), manajemen sumber daya manusia adalah perencanaan, pengorganisasian, pengarahan dan pengawasan dan pengadaan, pengembangan, pemberian kompensasi, pengintegrasian dan pemeliharaan tenaga kerja dengan maksud untuk membantu mencapai tujuan perusahaan. Tujuan utama manajemen sumber daya manusia adalah untuk meningkatkan kontribusi pegawai terhadap organisasi dalam rangka mencapai produktivitas organisasi yang bersangkutan. Hal ini dapat dipahami karena semua kegiatan organisasi tergantung kepada manusia yang mengelola organisasi yang bersangkutan. Oleh sebab itu, sumberdaya manusia tersebut harus dikelola agar dapat berdaya guna dan berhasil guna dalam mencapai tujuan organisasi.

\section{b. Defenisi Motivasi}

Motivasi adalah proses psikologis yang mendasar dan merupakan salah satu unsur yang dapat menjelaskan perilaku seseorang. Motivasi berasal dari kata "movere" dalam bahasa latin yang berarti "bergerak" atau "menggerakkan". Motivasi adalah suatu dorongan untuk memicu seorang individu dalam melakukan sesuatu kegiatan ataupun pekerjaan dalam sebuah perusahaan supaya dapat bekerja lebih maksimal atau sesuai dengan apa yang di harapkan, maka dari itu ada juga yang mengartikan motivasi sama dengan semangat. Menurut beberapa ahli, motivasi didefinisikan sebagai berikut :

1) Hamzah B. Uno (2003:102) dalam Anwar Prabu mangkunegara mengatakan bahwa motivasi adalah dorongan dasar yang menggerakkan tingkah laku seseorang. Dorongan ini berada pada diri seseorang yang menggerakkan untuk melakukan sesuatu yang sesuai dengan dorongan dalam dirinya. Oleh karena itu, perbuatan seseorang yang didasarkan atas motivasi tertentu mengandung tema sesuai dengan motivasi yang mendasarinya.

2) Christine Harvey (2002:154) dalam Desller Gery mengatakan bahwa motivasi adalah komoditi yang sangat dibutuhkan oleh semua orang.

3) Thomas L. Good dan Jere E. Brophy (2003:276) dalam Bambang Wahyudi mengatakan bahwa motivasi sebagai konstruk hipotesis yang digunakan untuk menjelaskan keinginan, arah, intensitas, dan keajegan perilaku yang diarahkan oleh tujuan.

4) Don Hellriegel dan Jhon W. Slocum (2002:108) dalam Ahmad Tohari mengatakan bahwa motivasi adalah proses psikologis yang dapat menjelaskan perilaku seseorang. Perilaku hakikatnya merupakan orientasi pada satu tujuan. Dengan kata lain, perilaku seseorang dirancang untuk mencapai tujuan. Untuk mencapai tujuan tersebut diperlukan proses interaksi dari beberapa unsur. Dengan demikian, motivasi merupakan kekuatan yang mendorong seseorang melakukan sesuatu untuk mencapai tujuan.

5) Menurut Hasibuan (2010:92), “motivasi adalah pemberian daya penggerak yang menciptakan kegairahan kerja bawahan, agar mereka mau bekerja keras memberikankemampuan dan keterampilanya untuk mewujudkan tujuan perusahaan." 
Dari definisi diatas, maka motivasi dapat didefinisikan sebagai masalah yang sangat penting dalam setiap usaha kelompok orang yang bekerja sama untuk mencapai tujuan organisasi, masalah motivasi dapat dianggap simpel karena pada dasarnya manusia mudah dimotivasi, dengan memberikan apa yang diinginkannya. Masalah motivasi, dianggap kompleks, karena sesuatu dianggap penting bagi orang tertentu.

\section{c. Dimensi Motivasi}

Untuk dapat memotivasi seseorang diperlukan pemahaman tantangan bagaimana proses terbentuknya motivasi kerja. Oleh karena itu menurut Frederick Herzberg dalam buku Donni Juni (2014:212), ada 2 macam teknik motivasi kerja yang dapat digunakan :

1 Faktor Pemeliharaan (Maintenance Factors), yaitu faktor-faktor pemeliharaan yang berhubungan dengan hakikat manusia yang ingin memperoleh ketentraman badaniah. Bisa disebut juga sebagai faktor esktrinsik seperti :

1) Kebijaksaan: sifat dan kemampuan untuk menggunakan pengetahuan, pemahaman, pengalaman, akalsehat dan wawasan yang dalam

2) Supervisi : pengarahan serta pengendalian kepada tingkat karyawan yang berada di bawahanya dalam suatu organisasi atau kelompok

3) Upah/gaji : sejumlah pembayaran kepada pegawai yang diberi tugas administrative dan manajemen yang biasanya ditetapkan perbulan

4) Hubungan antar pribadi: kemampuan untuk mengadakan dan mempertahankan hubungan yang baik antar anggota dalam organisasi

5) Kondisi kerja : lingkungan kerja yang langsung berhubungan dengan pengawai seperti pusat kerja, kursi, meja dan sebagainya.

2 Factor Motivasi (motivation Factors), yaitu faktor motivator yang menyangkut kebutuhan psikologis seseorang yaitu perasaan sempurna dalam melakukan pekerjaan. Factor motivasi ini berhubungan dengan penghargaan terhadap pribadi yang berkaitan langsung dengan pekerjaan. Bisa disebut juga faktor intrinsik seperti :

1) Keberhasilan : kemampuan untuk melewati dan mengatasi dari satu kegagalan ke kegagalan berikutnya tanpa kehilangan semangat

2) Pengakuan atau penghargaan : kebutuhan untuk dihormati dan dihargai oleh orang lain.

3) Pekerjaan itu sendiri : perasaan mendukung atau tidak mendukung yang dialami pegawai dalam bekerja

4) Tanggung jawab : sikap yang senantiasa menyelesaikan tugas dengan penuh kesadaran

5) Pengembangan : Suatu usaha untuk meningkatkan kemampuan teknis, teoritis,konseptual dan moral karyawan sesuai dengan kebutuhan pekerjaan/ jabatan melalui pendidikan dan pelatihan.

\section{d. Teori Motivasi}

1. Teori X dan Teori Y McGregor 
Douglas McGregor mengemukakan dalam dua pandangan nyata mengenai manusia yaitu pandangan pertama pada dasarnya negatif, disebut Teori $X$, dan yang kedua pada dasarnya positif, disebut Teori Y. McGregor menyimpulkan bahwa pandangan manajer mengenai sifat manusia didasarkan atas beberapa kelompok asumsi tertentu dan bahwa mereka cenderung membentuk perilaku mereka terhadap karyawan berdasarkan asumsi-asumsi tersebut. Mc Gregor dalam Robbins (2008:225), Menurut teori $\mathrm{X}$ empat asumsi yang dimiliki oleh manajer adalah:

1) Karyawan pada dasarnya tidak menyukai pekerjaan, dan sebisa mungkin berusaha untuk menghindarinya.

2) Karena karyawan tidak menyukai pekerjaan, mereka harus dipaksa, dikendalikan, atau diancam dengan hukuman untuk mencapai tujuan-tujuan.

3) Karyawan akan menghindari tanggungjawab dan mencari perintah formal bila mungkin.

4) Sebagian karyawan menempatkan keamanan diatas semua faktor lain terkait pekerjaan dan emnunjukan sedikit ambisi.

Bertentangan dengan pandangan-pandangan negatif mengenai sifat-sifat manusia dalam Teori X, McGregor menyebutkan empat asumsi positif yang disebut Teori Y:

1) Karyawan menganggap kerja sebagai hal yang menyenangkan, seperti halnya istirahat atau bermain.

2) Karyawan akan berlatih mengendalikan diri dan emosi untuk mencapai berbagia tujuan.

3) Karyawan bersedia belajar untuk menerima, bahkan mencari, tanggungjawab.

4) Karyawan mampu membuat berbagai kepuutusan inovatif yang diedarkan ke seluruh populasi, dan bukan hanya bagi mereka yang menduduki posisi manajemen.

2. Teori Dua Faktor Frederick Herzberg

Ada dua jenis faktor yang mendorong seseorang untuk berusaha mencapai kepuasan dan menjauhkan diri dari ketidakpuasan. Dua faktor itu disebutnya factor higiene (faktor ekstrinsik) dan faktor motivator (faktor intrinsik). Faktor ekstrinsik memotivasi seseorang untuk keluar dari ketidakpuasan, termasuk di dalamnya adalah kebijakan personalia dan praktek-praktek manajemen perusahaan dimana suatu pekerjaan dilakukan, supervisi teknis yang diterima pada pekerjaan tersebut, hubungan antara individu dengan supervisor dan kolega, dan kualitas kerja. Sedangkan faktor motivator, memotivasi seseorang untuk berusaha mencapai kepuasan, yang termasuk didalamnya adalah pencapaian dan penyelesaian pada suatu pekerjaan, pengenalan untuk menyelesaikan pekerjaan, sifat pekerjaan dan tugas itu sendiri.

\section{e. Prinsip dan Teknik Motivasi}

Motivasi yang diberikan manajer kepada karyawan tentunya harus menggunakan prinsip-prinsip yang harus dijadikan pedoman oleh manajer untuk 
memotivasi karyawannya. Menurut Mangkunegara (2003:93), menyatakan prinsipprinsip dalam memotivasi kinerja karyawan adalah sebagai berikut:

1) Prinsip partisipasi yaitu dalam upaya memotivasi kerja, karyawan perlu diberikan kesempatan untuk ikut berpartisipasi dalam menentukan tujuan yang akan dicapai oleh manajer.

2) Prinsip komunikasi yaitu manajer mengkomunikasikan segala sesuatu yang berhubungan dengan usaha pencapaian tugas, dengan informasi yang jelas, karyawan akan lebih mudah dimotivasi kerjanya.

3) Prinsip mengakui andil bawahan yaitu manajer mengakui bahwa bawahan (karyawan) mempunyai andil didalam usaha pencapaian tujuan. Dengan pengakuan tersebut, karyawana akan lebih mudah dimotivasi kerjanya.

4) Prinsip pendelegasian wewenang yaitu manajer memeberikan otoritas atau wewenang kepada karyawan untuk sewaktu-waktu dapat mengambil keputusan terhadap pekerjaan yang dilakukannya, hal itu akan membuat karyawan yang bersangkutan menjadi termotivasi untuk mencapai tujuan yang telah ditetapkan oleh manajer.

5) Prinsip memberi perhatian yaitu manajer memberikan perhatian terhadap apa yang diinginkan oleh karyawan. Maka karyawanpun akan termotivasi untuk bekerja sesuai apa yang diharapkan oleh manajer.

Penggunaan masing-masing alat motivasi ini dengan segala bentuknya haruslah mempertimbangkan situasi dan orangnya sebab pada hakekatnya individu adalah berbeda dengan yang lainnya. Menurut Hasibuan (2010:99), menyatakan Alat-alat tentang pelaksanaan motivasi yakni sebagai berikut:

1) Material insentif, yaitu alat-alat motivasi yang diberikan itu berupa uang, dan atau barang yang mempunyai nilai pasar, jadi memberikan kebutuhan ekonomis. Misalnya: kendaraan, rumah dan lain-lain.

2) Non material insentif, yaitu alat motivasi yang diberikan itu berupa barang atau benda yang tidak ternilai, jadi hanya memberikan kepuasan atau kebanggaan rohani saja. Misalnya: medali, piagam, bintang jasa dan lain-lain.

3) Kombinasi material dan non material, yaitu alat motivasi yang diberikan itu berupa materil (uang dan barang), serta non materil (medali atau piagam), jadi memenuhi kebutuhan ekonomis dan kepuasan atau kebanggan rohani.

Dari pendapat diatas, menerangkan bahwa kebutuhan bersifat materil adalah bersifat besar upah atau penerimaan-penerimaan lain yang dapat berupa uang, beras, gula, rokok serta kebutuhan pokok lainnya. Sedangkan kebutuhan yang bersifat non materil merupakan kebutuhan-kebutuhan yang diperlukan bilamana dipenuhi akan dapat menimbulkan kepuasan.

\section{e. Produktivitas}

Menurut Paul Mali (2001:67) yang di Kutip oleh sedarmayanti dalam bukunya menyatakan bahwa produktivitas adalah bagaimana menghasilkan atau meningkatkan hasil barang dan jasa semakin tinggi dengan memanfaatkan sumberdaya 
secara efisien. Oleh karena itu produktivitas sering diartikan sebagai rasio masukan dan keluaran dalam satuan waktu tertentu. Menurut Yuniarsih dan Suwarno (2008:156) menyatakan bahwa produktifitas merupakan hasil konkrit (produk) yang dihasilkan oleh individu atau kelompok,selama satuan waktu tertentu dalam proses kerja. Selain itu Whitmore dalam buku Sedarmayanti (2001:58) memandang sebagai berikut bahwaproduktivitas sebagai salahsatu ukuran atas penggunaan sumber daya dalam suatu organisasi dan biasanya sebagai rasio dari keluaran yang dicapai dan sumberdaya yang digunakan. Dan menurut Sedarmayanti (2001:58) mengemukakan bahwa: "dengan kata lain dapat dikatakan pengertian produktivitas memiliki dua dimensi yaitu efektivitasdan efesiensi, dimensi pertama berkaitan pencapaian untuk kinerja yang maksimal, dengan artian pencapaian target yang berkaitan dengan kualitas, kuantitas, dan waktu. Sedangkan dimensi yang kedua berkaitan dengan upaya membandingkan masukan dengan realisasi penggunaan atau bagaimana pekerjaan tersebut dilaksanakan."

\section{Metode Penelitian}

Dalam penelitian ini, penulis menggunakan pendekatan kuantitatif dengan metode penelitian deskriptif dan asosiatif. Menurut sugiyono (2012:29), "Penelitian diskriptif adalah penelitian yang dilakukan untuk mengetahui nilai variabel mandiri, baik satu variabel atau lebih (independen) tanpa membuat perbandingan, atau menghubungkan dengan variabel yang lain". Selanjutnya "Penelitian asosiatif merupakan penelitian yang bertujuan untuk mengetahui pengaruh ataupun juga hubungan antara dua variabel atau lebih". Dengan penelitian asosiatif ini maka akan dapat dibangun suatu teori yang dapat berfungsi untuk menjelaskan, meramalkan, dan mengontrol suatu gejala.

\section{Hasil dan Pembahasan}

\section{a. Sejarah Perkembangan PT. Fastrata}

Kapal Api Global adalah perusahaan holding yang terdiri dari tujuh unit usaha, yaitu Sulotco Aaya Abadi, Santos Jaya Badi, Agel Langgeng, Fastrata Buana, Excelso Multi Rasa, Santos Premium Krimer dan Weiss tek. Kembali pada tahun 1927, Kapal Api pertama berlayar disurabaya sebagai bisnis rumah- tumbuh dipelopori oleh Mr. GO Soe Loet semangatnya hidup untuk menginspirasi generasi berikutnya yang, dari waktu ke waktu, Kapal Api diperluas menjadi tujuh unit bisnis yang berfokus pada makanan dan minuman. Kembali pada tahun 1927, perusahaan pertama berlayar di jalan panggung No. 9, Surabaya, Sebagai bisnis rumah-tumbuh memproduksi bermerek kopi bubuk. Ide untuk berbisnis baru ini berasal dari Mr. Go Soe Loet. Menyadari peluang pasar yang berpotensi besar dan antusiasme masyarakat untuk produk kopi, dan merasaperlu untuk memilih nam merek yang cocok dengan citra produk. Nama merek yang dipilih adalah "Kapal Api" atau "Steamboat" karena pada 
saat kapal uap adalah cara yang paling inovatif dan modern transportasi laut yang membawa harapan baru bagi umat manusia dalam perdagangan dunia. Steamboat itu dianggap sebagai symbol supremasi teknologi modern, kualitas, ketenaran dan kebanggan. Dengan nama merek Kapal Api lebih banyak dikenal di kalangan pecinta kopi Indonesia, Industri rumah tumbuh pesat. Bisnis ini kemudian disampaikan kepada anak Mr. Go Soe Loet yaitu, Mr Indra Boedino, Pak Soedomo Mergonoto dan Mr Singgih Gunawan. Selalu menempatkan kualitas produk sebagai prioritas nomor satu, bisnis mulai menunjukan perkembangan signifikan. Kopi Kapal Api mendominasi pangsa pasar di Indonesia dan memperluas ke pasar Internasional. Merek kopi lain yang diluncurkan kemudian mendirikan Kapal Api sebagai pemimpin pasar bawah perusahaan Pt Santosa Jaya Abadi. Usaha tidak berhenti disitu. Gairah Mr. Go Soe Loet yang tinggal untuk menginspirasi generasi berikutnya untuk memperluas ke bisnis makanan dan minuman lain yang meliputi pendirian: PT Agel Langgeng yang menjual permen dan sekarang berkembang ke biscuit. Excelso Café yang merupakan perpanjangan café bisnis kopi dan PT. Fastrata Buana yang berfungsi untuk mendistribusikan produk kopi dan permen ke seluruh wilayah Indonesia. Untuk mendukung bisnis kelompok, tiga perusahaan lainnya yang didirikan: PT. Sulotco Jaya Abadi yang beroprasi perkebunan Kopi, PT. Santosa Premium Krimer yang menghasilkan non-dairi creamer dan PT. Weiss Tek yang memproduksi mesin-mesin produksi dan mesin espresso. Kapal Api Global didirikan pada tahun 2009 sebagai perusahaan induk terdiri dari tujuh unit bisnis dengan motivasi untuk menjadi lebih agresif dan professional dalam mengembangkan bisnis Kapal Api Group di masa depan. PT. Fastrata Buana adalah salah satu perusahaan bisnis Kapal Api Grup yang bergerang dalam bidang distribusi consumer goods. PT. Fastrata Buana Cabang Subang terletak di Jl. Oto Iskandardinata suka melang kec. subang kab. subang, Jawa Barat. Didirikan pada tahun 1992. Area distribusi PT. Fastrata Buana menjangkau seluruh wilayah nusantara dengan produk-produk bermutu tinggi ( kopi Kapal Api, Kopi ABC, Good Day, Relaxa,Say,Kiss dan lain-lain).

Visi PT. Fastrata Buana : Menjadi Perusahaan distribusi terbaik dan tumbuh cepat. Misi PT. Fastrata Buana : Mendistribusikan produk konsumen yang bermutu di seluruh Indonesia dengan mengutamakan kepuasan pelanggan dan pertumbuhan nilai bagi pemegang saham melalui pengembangan dan pemberdayaan Sumber Daya Manusia. PT Fastrata Buana didirikan pada tahun 1992 di Jakarta . Fastrata Buana menangani penjualan dan distribusi produk Kapal Api Group untuk memastikan pengiriman ke pelanggan. Fastrata Buana adalah perusahaan distribusi terbesar di Indonesia dengan cabang dan titik distribusi di Sumatera, Jawa, Bali, Kalimantan, Sulawesi dan bahkan Papua . Fastrata Buana mendukung 400 ribu outlet liputan langsung dengan kemampuan menjangkau seluruh wilayah Indonesia. Untuk cepat memperbaiki layanan dan distribusi ke seluruh wilayah Indonesia, Fastrata Buana secara bertahap memperluas lokasi cabang yang ada dengan membangun cabang baru atau lembaga untuk memenuhi kebutuhan konsumen di daerah-daerah dengan potensi pasar masa depan yang potensial. PT. Fastrata Buana memiliki fasilitas gudang dengan kapasitas penyimpanan yang tinggi yang dilengkapi dengan sistem manajemen persediaan yang 
canggih untuk memastikan bahwa produk selalu siap dan tersedia di pasar. Sebagai salah satu bagian yang paling penting dari sebuah perusahaan distribusi, armada Fastrata Buana mencakup ribuan besar, menengah dan kendaraan kapasitas kecil untuk memastikan produk yang baik didistribusikan ke semua tingkatan - dari grosir, semigrosir, pengecer di semua daerah di Indonesia. PT. Fastrata adalah bisnis profesional dioperasikan dilengkapi dengan orang-orang yang handal dan terampil dengan integritas yang tinggi. Selain itu hal ini didukung oleh teknologi informasi terbaru memastikan on-line, real-time dan akses informasi yang lengkap sehingga semua distribusi dan data penjualan dapat digunakan oleh mitra bisnis untuk membuat keputusan dengan cepat dan akurat.

\section{b. Pengujian Instrumen Penelitian}

Variabel penelitian ini terdiri dari dua variabel, yaitu variabel saluran distribusi sebagai variabel bebas yang diberi symbol $X$, dan variable volume penjualan sebagai variabel tidak bebas yang diberi symbol Y. pada penelitian ini yang dijadikan sebagai unit analisis adalah para karyawan PT. Fastrata Buana Subang, dengan keseluruhan jumlah karyawan sebanyak 91 orang, namun sampel yang diambil sebanyak 75 orang sebagai responden. Selanjutnya kepada responden tersebut diajukan pernyataan-pernyataan dalam bentuk angket yang merupakan penjabaran dari indikator-indikator variabel saluran distribusi dan variabel volume penjualan. Indikator-indikator dalam setiap variabel penelitian dituangkan ke dalam pernyataan, dimana setiap pernyataan angket memiliki lima alternatif jawaban yang dapat dipilih oleh responden. Alternatif tersebut diberi skor dari 5 sampai 1 sesuai dengan skala likert sehingga diperoleh data ordinal. Data ordinal tersebut kemudian ditransformasi ke dalam interval.

\section{c. Hasil Uji Validitas}

Instrumen penelitian diujicoba dengan tujuan untuk mengetahui apakah instrumen telah memenuhi persyaratan ditinjau dari segi kesahihan/validitas maupun dari segi keterandalan/reliabilitasnya. Instrumen dikatakan valid apabila mampu mengukur apa yang diinginkan. Tinggi rendahnya validitas instrumen menunjukkan sejauh mana data yang terkumpul tidak menyimpang dari gambaran tentang variabel yang dimaksud. Alat pengujian yang dipakai adalah Korelasi Product Moment sebagai berikut:

Penentunan nilai korelasi (r)

Untuk menentukan nilai korelasi, digunakn rumus sebagai berikut:

Kaidah keputusan

$$
r_{x y}=\frac{n \sum x y-\left(\sum x\right)\left(\sum y\right)}{\sqrt{\left\{n \sum x^{2}-\left(\sum x\right)^{2}\right) n \sum y^{2}-\left(\sum y\right)^{2}}}
$$

Nilai $r_{\text {hitung }}$ kemudian dibandingkan dengan nilai $r_{\text {tabel }}$ dengan tingkat tertentu dan derajat bebas sebesar n-2. Kaidah keputusan sebagai berikut :

a. Jika $\mathrm{r}_{\text {hitung }} \geq \mathrm{r}_{\text {tabel }}$ maka alat ukur yang digunakan valid 


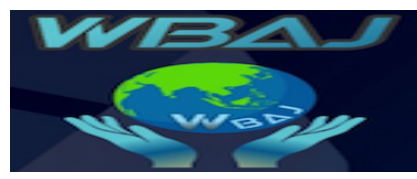

Volume 1 Issue 2, Desember 2019

b. Jika $r_{\text {hitung }}<r_{\text {tabel }}$ maka alat ukur yang digunakan tidak valid

Untuk menguji validitas setiap item maka skor-skor yang ada pada item yang dimaksudkan dikorelasikan dengan skor total. Skor item dipandang sebagai nilai $X$ dan skor total dipandang sebagai $Y$, dengan diperolehnya indeks validitas setiap item dapat diketahui dengan pasti item-item manakah yang tidak memenuhi syarat ditinjau dari validitasnya. Berdasarkan informasi tersebut peneliti dapat mengganti ataupun merevisi item-item dimaksud. Bagi peneliti yang menginginkan, pengujian terhadap item dapat dilakukan dengan mengkorelasikan item dengan skor total pada variabel. Hasil uji validitas terhadap variabel Motivasi (X) dengan menggunakan SPSS 16, hasilnya sebagai berikut:

Tabel 2

Hasil Uji Validitas Variabel Motivasi (X)

\begin{tabular}{|c|c|c|c|}
\hline Item & R Korelasi antara butir \& skor & r Tabel & Kesimpulan \\
\hline 1 & 0,520 & 0.22 & Valid \\
\hline 2 & 0,454 & 0.22 & Valid \\
\hline 3 & 0,414 & 0.22 & Valid \\
\hline 4 & 0,396 & 0.22 & Valid \\
\hline 5 & 0,678 & 0.22 & Valid \\
\hline 6 & 0,525 & 0.22 & Valid \\
\hline 7 & 0,648 & 0.22 & Valid \\
\hline 8 & 0,592 & 0.22 & Valid \\
\hline 9 & 0,537 & 0.22 & Valid \\
\hline 10 & 0,442 & 0.22 & Valid \\
\hline
\end{tabular}

Sumber: Hasil Pengolahan Data, 2017

Berdasarkan Tabel 4.6, hasil uji validitas variabel Motivasi $(X)$ diperoleh gambaran bahwa uji instrumen untuk variabel motivasi menunjukan bahwa semua pernyataan 10 item dapat dikatakan valid, karena koefisien yang dihasilkan lebih besar dari 0,22. Nilai tertinggi adalah pernyataan butir ke 5 sebesar 0,678 dan nilai terendah adalah pernyataan butir ke 4 sebesar 0,396 sehingga semua data bisa dilanjutkan ke analisis berikutnya.

Uji validitas untuk variabel Produktivitas kerja (Y), hasil perhitungaannya dapat dijelaskan pada tabel 4.7 sebagai berikut:

Tabel 3

Hasil uji Validitas Variabel Produktivitas Kerja (Y)

\begin{tabular}{|c|c|c|c|}
\hline Item & $\begin{array}{c}\text { R Korelasi antara butir \& } \\
\text { skor }\end{array}$ & r Tabel & Kesimpulan \\
\hline 1 & 0,633 & 0.22 & Valid \\
\hline 2 & 0,517 & 0.22 & Valid \\
\hline 3 & 0,505 & 0.22 & Valid \\
\hline 4 & 0,475 & 0.22 & Valid \\
\hline 5 & 0,545 & 0.22 & Valid \\
\hline
\end{tabular}




\begin{tabular}{|c|c|c|c|}
\hline 6 & 0,686 & 0.22 & Valid \\
\hline 7 & 0,432 & 0.22 & Valid \\
\hline 8 & 0,432 & 0.22 & Valid \\
\hline 9 & 0,475 & 0.22 & Valid \\
\hline 10 & 0,480 & 0.22 & Valid \\
\hline
\end{tabular}

Sumber: Hasil Pengolahan Data

Berdasarkan Tabel 3 hasil uji validitas variabel produktivitas kerja (Y) diperoleh gambaran bahwa uji instrumen untuk variabel produktivitas kerja menunjukan bahwa semua pernyataan 10 item dapat dikatakan valid, karena koefisien yang dihasilkan lebih besar dari 0,22. Nilai tertinggi adalah pernyataan butir ke 6 sebesar 0,686 dan nilai terendah adalah pernyataan butir ke 7 dan 8 sebesar 0,432 sehingga semua data bisa dilanjutkan ke analisis berikutnya untuk dianalisis lebih lanjut dalam pengujian hipotesis.

\section{d. Uji Reliabilitas}

Reliabilitas menunjuk pada pengertian bahwa sesuatu instrumen cukup dipercaya untuk digunakan sebagai alat pengumpul data karena instrumen tersebut sudah baik. Instrumen yang baik tidak akan bersifat tendensius mengarahkan responden untuk memilih jawaban-jawaban tertentu.

Instrumen yang reliabel akan menghasilkan data yang dapat dipercaya juga. Data yang benar sesuai dengan kenyataannya, maka berapa kali pun diambil, tetap akan sama. Instrumen dikatakan reliabel jika memiliki Cronbach kurang dari 0,60 adalah kurang baik, sedangkan 0,7 dapat diterima, dan diatas 0,8 adalah baik.Untuk mengukur reliabilitas kuesioner dalam penelitian ini digunakan "Metode Alpha Cronbach" dengan rumus :

$$
r=\left(\frac{k}{k-1}\right)\left(1-\frac{\sum V_{i}}{V_{t}}\right)
$$

Berdasarkan hasil perhitungan rumus Alpha Cronbach dengan menggunakan SPSS 16, maka diperoleh keputusan koefisien reliabilitas dari penelitian sebagai berikut:

Tabel 4

\section{Hasil Uji Reliabilitas Instrumen Penelitian Reliability Statistics}

\begin{tabular}{|r|r|}
\hline Cronbach's Alpha & N of Items \\
\hline .823 & 20 \\
\hline
\end{tabular}

Tabel 4 menunjukkan bahwa variabel penelitian mempunyai nilai Reliabilitas sebesar 0,823 yang berada diatas 0,8 maka dikategorikan reliabilitas baik, maka uji reliabilitas tersebut dinyatakan Reliabel. Keputusan hasil uji reliabilitas ini menunjukkan bahwa seluruh item dari variabel motivasi dan variabel produktivitas kerja sebagaimana telah dioperasionalisasikan pada operasionalisasi variabel dapat diterima keandalannya atau kekonsistensinannya. 


\section{e. Pengujian Hubungan (Asosiatif)}

Pengujian hubungan (Asosiatif) untuk melihat ada atau tidaknya hubungan motivasi terhadap produktivitas kerja pada PT Fastrata Buana di Subang. Maka sebelumnya telah diajukan hipotesis penelitian sebagai berikut: "terdapat pengaruh motivasi terhadap produktivitas kerja pada PT. Fastrata Buana di Subang". Pengujian hubungan antara motivasi terhadap produktivitas kerja dicari berdasarkan hasil pengujian SPSS 16 dan menggunakan rumus koefisien korelasi. Statistik uji ini dipilih berdasarkan bentuk data diolah berskala ordinal kemudian ditransformasikan ke dalam bentuk data interval. Berdasarkan hasil perhitungan dengan menggunakan SPSS 16 dapat dilihat dalam bentuk tabel sebagai berikut:

\section{Tabel 4}

\section{Pengujian Hubungan (Asosiatif)}

\begin{tabular}{|ll|r|r|}
\hline \multicolumn{1}{|c|}{ Correlations } & \multicolumn{1}{c|}{$\begin{array}{c}\text { Produktivita } \\
\text { s Kerja }\end{array}$} & Motivasi \\
\hline Pearson \\
Correlation & $\begin{array}{l}\text { Produktivitas } \\
\text { Kerja } \\
\text { Motivasi }\end{array}$ & 1.000 & .709 \\
& Produktivitas & .709 & 1.000 \\
\hline Kerja & & .000 \\
& Motivasi &. & \\
\hline & $\begin{array}{l}\text { Produktivitas } \\
\text { Kerja }\end{array}$ & .000 & 75 \\
& Motivasi & 75 & 75 \\
\hline
\end{tabular}

Berdasarkan tabel diatas, dapat dijelaskan bahwa antara variabel saluran distribusi terhadap volume penjualan pada PT Frastrata Buana di Subang "kuat" dengan nilai 0,709 .

\section{f. Analisis Regresi}

Analisis regresi digunakan untuk melihat pengaruh motivasi terhadap produktivitas kerja di PT Frastrata. Dengan demikian dapat diketahui persamaan regresi berdasarkan perhitungan dengan menggunakan SPSS 16 dapat dilihat dalam bentuk tabel 4.13 berikut ini:

Tabel 5

Analisis Regresi

Coefficients ${ }^{a}$ 


\begin{tabular}{|c|c|c|c|c|c|}
\hline \multirow[b]{2}{*}{ Model } & \multicolumn{2}{|c|}{$\begin{array}{l}\text { Unstandardized } \\
\text { Coefficients }\end{array}$} & \multirow{2}{*}{$\begin{array}{l}\text { Standardize } \\
\text { d } \\
\text { Coefficients } \\
\text { Beta }\end{array}$} & \multirow[b]{2}{*}{$\mathrm{t}$} & \multirow[b]{2}{*}{ Sig. } \\
\hline & $B$ & Std. Error & & & \\
\hline${ }_{\text {) }}^{\text {Constant }}$ & 9.074 & 2.777 & & 3.267 & .002 \\
\hline Motivasi & .726 & .084 & .709 & 8.600 & .000 \\
\hline
\end{tabular}

a. Dependent Variable: Produktivitas

Kerja

Berdasarkan hasil pengolahan data diperoleh Persamaan Regresi :

$\mathrm{Y}=\mathrm{a}+\mathrm{bX}$

$Y=9,074+0,726 X$

Dimana:

$X=$ Motivasi

$\mathrm{Y}=$ Produktivitas Kerja

$\mathrm{a}=$ nilai konstanta yang menunjukan bahwa jika motivasi tidak dipertimbangkan maka produktivitas kerja akan mencapai nilai sebesar 9,074.

$b=$ koefisien regresi sebesar 0,726 artinya setiap penambahan atau peningkatan $1 \%$ motivasi, maka akan meningkatkan produktivitas kerja sebesar 0,726 .

\section{g. Uji Regresi (Parameter ) Secara Parsial (Uji t)}

Uji regresi (Parameter ) secara pasrial (uji t) digunakan untuk menguji signifikasi pengaruh antara dua variabel, untuk itu harus dites apakah korelasi antara variabel motivasi $(\mathrm{X})$ dengan variabel produktivitas kerja $(\mathrm{Y})$ signifikan atau tidak, maka perlu dilakukan pengujian uji $t$, dengan menggunakan tingkat signifikasi 0,05 , sebagai berikut:

Ho : $\mathrm{P}=0$ : Tidak terdapat pengaruh antara motivasi terhadap produktivitas kerja PT Fastrata Buana di Subang

Ha : $\mathrm{P} \neq 0$ : Terdapat pengaruh antara motivasi terhadap produktivitas kerja PT Fastrata Buana di Subang

Hasilnya Jika $t_{\text {hitung }}>t_{\text {tabel }}$ maka Ho ditolak atau Ha diterima. Perhitungan uji hipotesis ini menggunakan SPSS 16

Berdasarkan tabel 5 diatas, diperoleh $t_{\text {hitung }}$ sebesar 8,600 dan selanjutnya menentukan $t_{\text {tabel, }}$, tabel distribusi $t$ dicari pada $=0,05$ dengan derajat bebas $\mathrm{N}-2$ yaitu $75-2=73$, maka $t_{\text {tabel }}$ diperoleh 1,665 Oleh karena $t_{\text {hitung }}$ lebih besar dari $t_{\text {tabel }}$ yaitu 8,600 $>$ 1,665 maka Ho ditolak, artinya terdapat pengaruh yang signifikan antara motivasi terhadap produktivitas kerja di PT FASTRATA BUANA atau dengan kata lain variabel Motivasi $(X)$ memberi pengaruh positif terhadap variabel Produktivitas Kerja $(\mathrm{Y})$.

\section{h. Analisis Koefisien Determinasi}




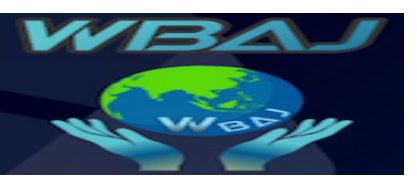

Volume 1 Issue 2, Desember 2019

http:/ / ejournal.unsub.ac.id/index.php/bisnis

Koefisien determinasi ini diperlukan untuk melihat seberapa besar pengaruh variabel X terhadap Y. Hasil perhitungan koefisien determinasi melalui SPSS 16 dapat dilihat dalam tabel sebagai berikut:

\section{Tabel 6 \\ Koefisien Determinasi}

\begin{tabular}{|c|c|c|c|c|c|c|c|c|c|}
\hline \multirow[b]{3}{*}{$\begin{array}{l}\text { Mod } \\
\text { el }\end{array}$} & \multicolumn{9}{|c|}{ Model Summary } \\
\hline & \multirow[b]{2}{*}{$\mathrm{R}$} & \multirow[b]{2}{*}{$\begin{array}{c}\mathrm{R} \\
\text { Squar } \\
\mathrm{e}\end{array}$} & \multirow[b]{2}{*}{$\begin{array}{c}\text { Adjus } \\
\text { ted R } \\
\text { Squar } \\
\text { e }\end{array}$} & \multirow{2}{*}{$\begin{array}{l}\text { Std. } \\
\text { Error of } \\
\text { the } \\
\text { Estimat } \\
\text { e }\end{array}$} & \multicolumn{5}{|c|}{ Change Statistics } \\
\hline & & & & & $\begin{array}{c}\text { R Square } \\
\text { Change }\end{array}$ & $\mid \begin{array}{c}F \\
\text { Chan } \\
\text { ge }\end{array}$ & df1 & $\mathrm{df} 2$ & $\begin{array}{l}\text { Sig. F } \\
\text { Change }\end{array}$ \\
\hline 1 & .709 & .503 & .496 & \begin{tabular}{|r|}
3.39554 \\
6
\end{tabular} & .503 & $\begin{array}{r}73.96 \\
3\end{array}$ & 1 & 73 & .000 \\
\hline
\end{tabular}

a. Predictors:

(Constant), Motivasi

b. Dependent Variable:

Produktivitas Kerja

Berdasarkan tabel diatas, menunjukan bahwa $\mathrm{R}$ square sebesar 0,503 atau 0,503 $\mathrm{x}$ $100 \%=50,3 \%$ yang berarti bahwa variabel independen (motivasi kerja) mempengaruhi variabel dependen (produktivitas kerja) sebesar 50,3\% dan sisanya sebesar 49,7\% yang diperkirakan dipengaruhi oleh faktor lain. Namun, faktor tersebut tidak diteliti lebih lanjut oleh peneliti melainkan dapat diteliti oleh peneliti lain sebagai acuan untuk diteliti dan dikembangkan lagi.

\section{Kesimpulan}

1. Variabel motivasi pada PT Fastrata Buana di Subang. Berdasarkan hasil jawaban responden ternyata jawabannya variatif, namun didominasi oleh tanggapan yang menjawab setuju, hal ini menunjukkan bahwa sebagian karyawan memiliki motivasi dalam bekerja dan motivasi karyawan harus terus ditingkatkan dalam upaya meningkatkan produktivitas kerja di perusahaan.

2. Variabel produktivitas kerja pada PT Fastrata Buana di Subang, berdasarkan hasil jawaban responden ternyata jawaban variatif, dengan jawaban positif, ragu-ragu hingga jawaban negative, namun didominasi oleh tanggapan yang menjawab setuju, hal ini menunjukkan bahwa ada beberapa karyawan yang mampu mencapai produktivitas kerjanya, produktivitas kerja karyawan harus ditingkatkan secara maksimal untuk mencapai tujuan perusahaan yang efektif dan efisien.

3. Berdasarkan kriteria interpretasi koefisien determinasi menunjukkan, bahwa terdapat pengaruh motivasi terhadap produktivitas kerja sebesar 50,3\% sedangkan 


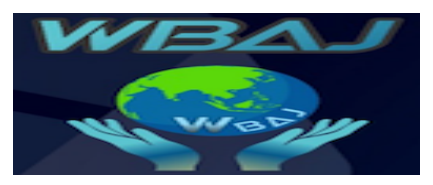

Volume 1 Issue 2, Desember 2019

http:/ / ejournal.unsub.ac.id/index.php/bisnis

49,7\% diperkirakan dipengaruhi oleh faktor lain Namun, faktor tersebut tidak diteliti lebih lanjut oleh peneliti melainkan dapat diteliti oleh peneliti lain sebagai acuan untuk diteliti dan dikembangkan lagi. Berdasarkan hasil regresi menunjukkan bahwa prediksi pengaruh motivasi terhadap produktivitas kerja berpengaruh positif. Artinya, motivasi berpengaruh terhadap produktivitas kerja.

\section{Referensi}

Ahmad Tohari, 2002, Pemahaman Praktis Manajemen Sumber Daya Manusia Bandung Universitas Tanjung Pura, Mandar Maju.

Bambang Wahyudi, 2003, "Manajemen Sumber Daya Manusia". Jakarta.

Desller Gery, 2002. Personal Manjemen, London : Mc. Daniel and Evass Ltd.

Hasibuan, Malayu, 2010, Manajemen Sumber Daya Manusia, edisi revisi, PT. Bumi Aksara, Jakarta.

Hasibuan, Malayu. 2001. Organisasi dan motivasi. Bumi Aksara: Jakarta.

Hani, Handoko. 2002. Manajemen Personalia dan Sumber Daya Manusia. BPFE: Yogyakarta

J. Ravianto, 2003. Produktivitas dan Manajemen. Jakarta : SIUP.

Mangkunegara, Anwar Prabu. 2003. Perencanaan dan Pengembangan Sumber Daya Masyarakat. Reflika Aditama: Jakarta.

Priansa, Juni Doni. 2014. Perencanaan dan Pengembangan Manajemen Sumber Daya Manusia. CV.Alfabeta: Jakarta.

Retno Damayanti, 2013, Pengaruh Motivasi terhadap Produktivitas kerja karyawan pada CV.Bening Natural Furniture Di Semarang, Universitas Gajah Mada

Robbins,Stephen . 2008. Perilaku organisasi buku I. Salemba Empat: Jakarta.

Siagian, Sondang P. 2003. Filsafat Administrasi. Bumi Aksara: Jakarta.

Sedarmayanti. 2001. Manajemen Sumber Daya Manusia dan Produktivitas Kerja. CV. Mandar Maja: Bandung.

Sugiyono. 2007. Metode Penelitian Bisnis. Alfabeta: Bandung.

Sugiyono. 2008. Metode penelitian Kuantitatif, Kualitatif dan RED. Alfabeta: Bandung. 


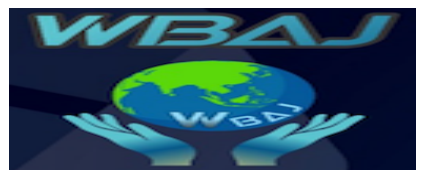

Volume 1 Issue 2, Desember 2019

http:/ / ejournal.unsub.ac.id/index.php/bisnis

Sugiyono. 2012. Statistika Untuk Penelitian, Alfabeta: Bandung.

Supriyanto, 2013, Pengaruh Pengawasan dan Semangat Kerja Terhadap Produktivitas Kerja Karyawan PT. Delta Marlin Dunia Tekstil di Karanganyar, Universitas Sriwijaya

Tjutju Yuniarsih, Suwatno.2008.Manajemen Sumber Daya Manusia,PT.Mandar Maju:Bandung 